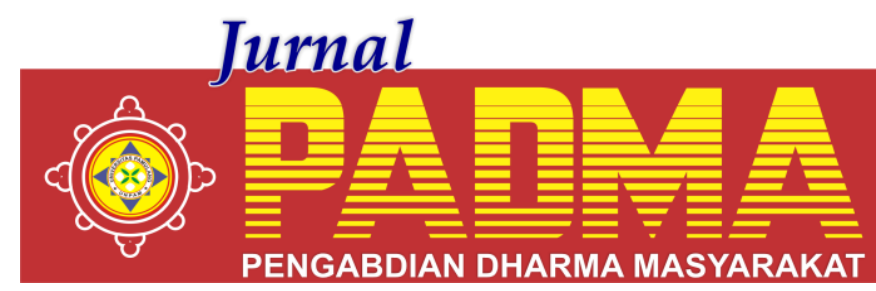

VOLUME 1, NOMOR 4, OKTOBER 2021

\title{
PENDIDIKAN KEWIRAUSAHAAN BAGI ANAK DIDIK PEMASYARAKATAN DI LEMBAGA PEMLPKA KHUSUS ANAK KELAS II JAKARTA
}

\author{
1Muhammad Irsyad Firdaus, ${ }^{2 *}$ Mahdi Adriansyah, ${ }^{3}$ Moh Jamaluddin, \\ ${ }^{4}$ Irfan Sudarso Gultom, 5 Nadya Fairuza \\ Universitas Pamulang, Tangerang Selatan, Banten, Indonesia \\ *mahdi.adriansyah@gmail.com
}

\begin{abstract}
Abstrak
Pelaku tindak pidana tidak hanya dilakukan oleh orang dewasa, melainkan anak-anak juga dapat melakukan tindak pidana. Mengenai pengertian anak-anak yang melakukan tindak pidana atau yang berkonflik dengan hukum diatur dalam Undang-Undang Nomor 11Tahun 2012 tentang Sistem Peradilan Pidana Anak. Dalam UU No 11 Tahun 2012, anak yang divonis bersalah dalam sistem peradilan anak mendapatkan pembinaan di LPKA. Salah satu pembinaan yang penting bagi anak sebagai bekal hidup ketika kelak kembalike masyarakat maka anak didik penting mendapatkan pendidikan kewirausahaan melalui program pembinaan di LPKA.
\end{abstract}

Kata Kunci: Pendidikan Kewirausahaan, Anak Didik, LPKA

Abstract
Criminals are not only committed by adults, but children can also commit criminal acts. Regarding the understanding of children who commit criminal acts or who are in conflict with the law regulated in Law No. 11 of 2012 concerning the Children's Criminal Justice System. In Law No. 11 of 2012, children convicted in the juvenile justice system get coaching at LPKA. One of the important coaching for children as a provision of life when later returned to the community then important students get entrepreneurial education through a coaching program at LPKA.

Keywords: Entrepreneurial Education, Protege, LPKA

\section{PENDAHULUAN}

Dalam melaksanakan tugas dan fungsinya Direktorat Jenderal Pemasyarakatan memiliki tugas memberikan bimbingan teknis dan supervisi di bidang registrasi, pelayanan tahanan, pembinaan narapidana, pembimbingan klien, pengentasan anak, pengelolaan benda sitaan dan barang rampasan negara, keamanan dan ketertiban, kesehatan dan perawatan narapidana dan tahanan, serta teknologi informasi pemasyarakatan. Lapas mempunyai tugas melaksanakan pemasyarakatan narapidana/anak didik. Lembaga Pemasyarakatan juga mempunyai fungsi melakukan pembinaan narapidana/anak didik, memberikan bimbingan, mempersiapkan sarana dan mengelola hasil kerja, melakukan bimbingan sosial/kerohanian narapidana/anak didik, melakukan pemeliharaan keamanan dan ketertiban Lapas, serta melakukan urusan tata usaha dan rumah tangga.
Pelaku tindak pidana tidak hanya dilakukan oleh orang dewasa, melainkan anakanak juga dapat melakukan tindak pidana. Mengenai pengertian anak-anakyang melakukantindak pidana atau yang berkonflik dengan hukum diatur dalam Undang-Undang Nomor 11Tahun 2012 tentang Sistem Peradilan Pidana Anak. Dalam UU No 11 Tahun 2012, anak yang divonis bersalah dalam sistem peradilan anak mendapatkan pembinaan di LPKA. Salah satu pembinaan yang penting bagi anak sebagai bekal hidup ketika kelak kembalike masyarakat maka anak didik penting mendapatkan pendidikan kewirausahaan melalui program pembinaan di LPKA.

Anak yang bersalah dan terbukti melakukan tindak pidana wajib ditempatkan ke dalam LPKA yang dulu dikenal sebagai Lapas Anak, sebagai salah satu upaya perlindungan intensif bagi anak dari dampak negatif pemenjaraan saat disatukan dengan penghuni dewasa. LPKA 
diharapkan lebih ramah bagi tumbuh kembang anak, dengan fokus pada kegiatan pendidikan dan pembinaan. Sebagaimana anak-anak pada kelompok usianya, anak yang menjalani pembinaan di LPKA sehubungan tindak pidana yang dilakukannya, mereka berhak memperoleh pembinaan, pembimbingan, pengawasan, pendampingan, pendidikan dan pelatihan, serta hak lain sesuai dengan ketentuan peraturan perundang-undangan. LPKA wajib menyelenggarakan pendidikan, pelatihan keterampilan, pembinaan, dan pemenuhan hak lain sesuai dengan ketentuan peraturan perundang-undangan. Tujuan dari pembinaan anak didik LPKA adalah untuk memberikan bimbingan kepada anak didik agar menyadari kesalahan, memperbaiki sikap, tidak mengulangi tindak kejahatan lagi sehingga diharapkan dapat diterima kembali dalam masyarakat (Tampubolon, 2017). Mengacu pendapat (Pratiwi \& Hastuti, 2017)sebagaimana mantan narapidana/anak didik LPKA akan menghadapi kemungkinan kurang berhasilnya untuk masuk kembali dalam kehidupan bermasyarakat. Hal ini dapat terjadi karena aksebilitas yang rendah dalam bidang pendidikan, pelatihan, dan dukungan moral dari keberadaan keluarga dan kerabat

Pada hakekatnya pendidikan merupakan proses yang berlangsung seumur hidup dan dilaksanakan di dalam lingkungan keluarga, sekolah dan masyarakat. Oleh karena itu Pendidikan adalah tanggungjawab bersama antara keluarga, masyarakat dan pemerintah. Pendidikan menurut pelaksanaannya dibagi menjadi pendidikan formal/sekolah dan pendidikan non formal/luar sekolah.

\section{METODE}

Lokasi pengabdian ada di Lembaga Pembinaan Khusus Anak Kelas II Jakarta, Jl. Raya Gandul Cinere. Khalayak sasaran dalam Pengabdian Kepada Masyarakat ini adalah seluruh peserta didik LPKA kelas II Jakarta, supaya dengan adanya pendidikan kewirausahaan yang baik akan memberikan wawasan terhadap peserta didik berkaitan dengan dunia usaha dalam upaya dan strategi mewujudkan peserta didik yang melek akan literasi bisnis di LPKA kelas II Jakarta. Pengabdian Kepada Masyarakat
(PKM) telah dilaksanakan di Lembaga Pembinaan Khusus Anak kelas II Jakarta, Jl. Raya Gandul Cinere pada tanggal 19 Januari 2021. Pelaksanaan kegiatan ini akan dibimbing oleh tim pelaksana staf-staf pengajar dari Universitas Pamulang dengan mengikut sertakan peran instansi terkait baik petugas maupun peserta anak didik LPKA kelas II Jakarta.

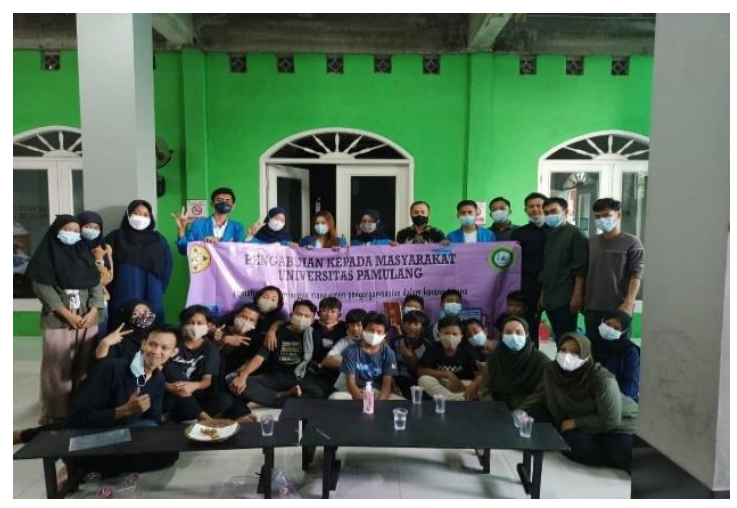

Gambar 1. Foto Bersama

Metode pelatihan yang diterapkan berdasarkan solusi atas permasalahan di LPKA kelas II Jakarta Pengabdian Kepada Masyarakat (PKM) akan dilaksanakan di LPKA kelas II Jakarta, Jl. Raya Gandul Cinere pada tanggal 19 Januari 2021, sebagai berikut :

Pendidikan yang dirancang untuk mengembangkan sumber daya manusia melalui rangkaian kegiatan identifikasi, pengkajian serta proses belajar yang terencana. Untuk mengatasi permasalahan yang ada, tim akan melakukan sosialisasi bagi seluruh peserta anak didik, termasuk petugas LPKA kelas II Jakarta tentang pendidikan kewirausahaan pada anak yang berhadapan dengan hukum. Adapun metode pelatihannya sebagai berikut :

1. Pengumpulan data, wawancara kepada peserta didik dan petugas LPKA kelas II Jakarta.

2. Pendidikan kewirausaah dengan memberikan sosialisasi kepada peserta anak didik dan petugas LPKA kelas II Jakarta.

\section{HASIL DAN PEMBAHASAN}

Menumbuhkan motivasi anak-anak didik untuk berwirausaha memang cukup sulit, hal itu akan terwujud apabila adanya kesadaran dari anak-anak didik saat mereka sudah benar-benar mencintai dunia 
kewirausahaan dan sadar akan keuntungannya saat mereka menjalaninya kelak. Tugas serta fungsi pegawai tentunya memberikan arahan dan motivasi serta berinovasi dalam memberikan praktek nyata yang menyenangkan kepada mereka. Para pegawai lapas juga diharapkan mampu melihat peluang berwirausaha di dunia digital saat ini. Sehingga anak-anak didik dilapas pun dibekali dengan kewirausahaan yang berbasis digital mengikuti perkembangan jaman yang semakin dinamis sebagai bekal mereka setelah keluar dari lapas.

Dari wawancara dengan para peserta didik dilapas, diketahui masih banyak anak yang belum berminat untuk berwirausaha. Anak-anak didik merasa mudah bosan dengan kegiatan keterampilan yang diadakan di lapas. Hanya beberapa anak yang bersemangat untuk mempelajari dunia kewirausahaan dengan fokus mengikuti berbagai pelatihan dan keterampilan yang di adakan lapas. Dibekali ilmu kewirausahaan dengan berbagai keterampilan yang diajarkan untuk para anak didik di usia yang masih muda sangat membantu dan memberikan dampak yang sangat positif untuk bekal mereka. Anak-anak didik dipersipkan untuk mengenali dunia kewirausahaan sejak dini agar dapat diimplementasikan di dalam kehidupan bermasyarakat saat mereka keluar dari lapas kelak.

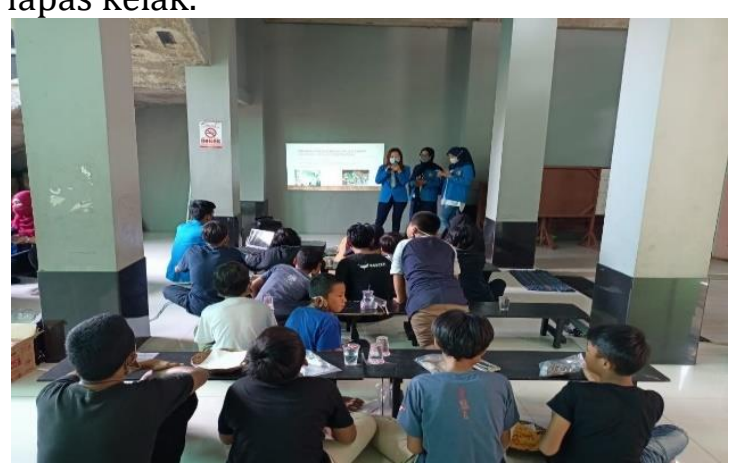

Gambar 2. Narasumber Memberikan Pelatihan

\section{PENUTUP}

1. Pemberian pendidikan tentang pengetahuan dasar dasar kewirausahaan sangat berpengaruh untuk meningkatkan Nilai kewirausahaan yang efektif bagi Anak Didik Pemasyarakatan di LPKA Kelas
II Jakarta

2. Minat belajar kewirausahaan peserta didik di LPKA Kelas II Jakarta menjadi faktor yang cukup berpengaruh dalam penyampaian materi kewirausahaan dan menentukan fokus usaha kedepan peserta didik.

3. LAPAS Kelas II Jakarta dalam pengembangan anak didik pemasyarakatan melalui pendidikan kewirausahaan untuk menghasilkan tenaga kerja terampil merupakan kepentingan bersama agar peserta didik dapat melanjutkan kehidupan bersosial dimasyarakan dengan lebih baik.

4. Pembelajaran pendidikan kewirausahaan meningkatkan pemahaman bagi anak didik pemasyarakatan di LPKA Kelas II Jakarta

5. Mengumpulkan segala kendala yang ditemukan dalam proses pendidikan kewirausahaan yang dilaksanakan untuk LAPAS Kelas II Jakarta dalam pengembangan anak didik pemasyarakatan melalui pendidikan kewirausahaan dan segera menindaklanjutinya.

6. Kerjasama dengan lembaga lembaga kewirausahaan dimasyarakat dan lebih mempersiapkan peserta didik untuk terjun nantinya dalam masyarakat.

7. Adanya tindak lanjut yang terus setelah pemberian materi kewirausahaan pada peserta didik LPKA Kelas II Jakarta

\section{DAFTAR PUSTAKA}

Darmawan, I. Y., \& Warmika, G. K. (2016). Pengaruh Norma Subjektif, Personal Attitude, Perceived Behavior Control, Dan Aspek Psikologis Terhadap Minat Wirausaha (Entrepreneurial Intention). E-Jurnal Manajemen Unud, 5(7), 4660-4689.

Deden Setiawan, 2016. Pengaruh Ekspektasi Pendapatan, Lingkungan Keluarga dan Pendidikan Kewiraushaaan Terhadap Minat Berwirausaha, Jurnal Profita, Vol 4 Edisi 7.

Erlangga, H. (2018). Spirit Pengembangan Kewirausahaan Di Perguruan Tinggi. Paradigma POLISTAAT: Jurnal Ilmu Sosial dan Ilmu Politik, 1(2), 102-127. 
Haque, M. G., et al. (2021). Micro Financial Sharia Non-bank Strategic Analysis: a Study at BMT Beringharjo, Yogyakarta. Budapest International Research and Critics Institute (BIRCIJournal): Humanities and Social Sciences, 4(2), 1677-1686.

Hendro. 2011. Dasar-dasar Kewirausahaan Panduan bagi Mahasiswa untuk Mengenal, Memahami, dan Memasuki Dunia Bisnis. Jakarta: Erlangga PT. Gelora Aksara Pratama, hlm. 29.

Insani, P. B. E. B. (2020). Hubungan Gaya Kepemimpinan Dengan Produktivitas Kerja Pegawai Bmt El Bina Insani Cugenang. Jurnal Agrita Vol, 2(1).

Isrososiawan, S. (2013). Peran Kewirausahaan dalam Pendidikan. Society, 9 (1)

Kurniati, Edi Dwi. 2015. Kewirausahaan Industri. Yogyakarta: Deepublish, hlm. 131.

Kyridis, A. Tsakiridou, E. Zagkos, C. Koutouzis, M \& Tziamtzi, C. (2011). "Educational inequalities and school droup in greece". International Journal of Education. Vol 3, No. 2: 3.

Mudyahardjo, Redja. 2012. Pengantar Pendidikan. Jakarta: PT. Raja Grafindo Persada, hlm. 11.

Muhadjir Darwin (eds). (2010). Dinamika kependudukan dan penguatan governance. Yogyakarta: Media Wacana, hlm. 271.

Nurjaya, N., et al. (2020). Edupreneurship management in shaping the nation's character. Jurnal Konseling dan Pendidikan, 8(3), 198-206.

Panpan Achmad Fadjri. (2000). "Analisis kualitas sumber daya manusia menurut kota di Indonesia", Warta Demografi, 30 No.3: 36.

Pratiwi, I., \& Hastuti, D. (2017). Kenakalan Pada Remaja Andikpas (Anak Didik
Lapas): Pengaruh Komunikasi Orang Tua atau Self-Esteem? Jurnal Ilmu Keluarga dan Konsumen. https://doi.org/10.24156/jikk.2017.1 0.1 .36

Saputra, Kiki. (2015). Pendidikan Berbasis Entrepreneurship. Yogyakarta: Diva Press, hlm. 19.

Suhartini, Yati. 2011. Analisis Faktor-Faktor yang Mempengaruhi Minat dalam Berwiraswasta. Jurnal AKMENIKA UPY. Vol. 7.

Susilowati, Tutik, dkk. 2013. Pengembangan Pendidikan Kewirausahaan Dalam Upaya Menumbuhkan Budaya Wirausaha Pada Siswa Sekolah Menengah Atas (SMA) di Kabupaten Karanganyar. JKB No. 12. Th.VII. Januari 2013.

Suyitno, Agus. 2013. Pendidikan Kewirausahaan Teori\&Praktik. Diakses pada tanggal 1 Desember 2014 dari

http://m.kompasmania.com/post/rea d/533892/1/pendidikan-

kewirausahaan-entrepreneurshipeducation-.html.

Tampubolon, E. (2017). Efektivitas Pembinaan Narapidana Anak Di Lembaga Pembinaan Khusus Anak (Lpka) Pekanbaru Oleh : Visip.

Todaro, M.P. dan Smith Stephen. C. 2003. Pembangunan Ekonomi di Dunia Ketiga. Edisi kedelapan. Jilid 2. Jakarta: Erlangga, hlm. 404.

Winarno. (2011). Pengembangan Sikap Entrepreneurship \& Intrapreneurship. Jakarta: PT Indeks.

Zubaedah, S. (2016). Keterampilan Abad Ke21: Keterampilan Yang Diajarkan Melalui Pembelajaran. Jurnal Penelitian Pendidikan. 